\title{
Information technology VS it's social concerns of health
}

Alireza Atarodi ${ }^{1}$, Ahmadreza Atarodi ${ }^{2}$

\author{
Journal of Research \& Health \\ Social Development \& Health Promotion \\ Research Center \\ Vol. 9, No.4, Jul \& Agu 2019 \\ Pages: 282- 283 \\ DOI: $10.29252 / j r h .9 .4 .282$ \\ Letter to Editor
}

1. Department of Knowledge and Information Science, Paramedical College and Social Development \& Health Promotion Research Center, Gonabad University of Medical Sciences, Gonabad, Iran

2. Correspondence to: Student Research Committee, School of Medicine, Gonabad University of Medical Sciences, Gonabad, Iran Email: a.atarodi.b@gmail.com

Received: 8 Apr 2019

Accepted: 1 May 2019

How to cite this article: Atarodi A, Atarodi A. Information technology VS it's social concerns of health. $J$ Research \& Health2019; 9(4): 282- 283 .

\section{Dear Chief in Editor}

Societies are mostly using smartphones and the World Wide Web in the era of information technology, (IT). Information technology and its impact is revealed to everyone on modern society. IT enables communication worldwide but reduced faceto-face interaction, reduced physical activity, made headache, fatness, heart disease, diabetes, neck pain, cost, job loss, and so many other health problems. Either way, IT systems that run can yield good and bad results. IT affects the environment, individuals and society as a whole. The way we use IT determines if its impacts are positive to society or negative. For example, we can make the most of our Internet smartphones and web to develop our societies, make them new and modern. Internet-based computers have changed the way people relate and make their living environment better, organize their work, their communities and their time and place faster, easier and cheaper than yesterday. IT has also put patients associated with the implementation and use of health information technology (HIT) at risk of harm and injury, creating new safety challenges for the healthcare system. Error reduction is a primary goal for the introduction of HIT, but unintended consequences arise with these new risks that adversely affect patient safety and quality. HIT integration creates new errors because of improper design, development, use, and implementation [1].

IT is produced largely in the form of smartphones and available web and easily prevailed everywhere, even for kids. A smartphone is a cell phone and studies show that excessive use of mobile phones can be linked to various aspects or mental health problems. Studies have also shown, for example, that mobile phone addiction can be related or effective on impulsiveness and addiction, low self-esteem and depression, control problems and the symptoms of depression, anxiety, Internet addiction and lower self-confidence, high impulsivity, feeling of loneliness and social anxiety, extroversion and self-esteem, depression, distractibility, lack of tolerance, withdrawal, escape, impulsivity, and negative consequences such as emotionally-damaged relationships and also reduction of academic achievement, family relationship decrease, social isolation, loneliness and depression [2]. Some studies have also revealed that smartphones empowered by the Global Mobile Communication System (GSM) protocol have emerged as the most prevalent means of voice communication and are mainly used by college students in Nigeria for many other reasons. Results showed that $38.2 \%$ of the students spent on their phones between 1 and 5 hours a day. Most respondents (98\%) used their phones to communicate with family and friends. Approximately 75 percent used their social networking smartphones. Only $24 \%$ of 
the students used their smartphones for academic activities. The study concluded that although smartphones were widely used among college students, they tended to use smartphones for social activities rather than academic activities that could be healthier and more useful [3]. It is now believed that smartphones as one of the IT applicants can jeopardize people's health with problems such as bad posture, blue screen light, and too much screen watching that makes addiction not good for our mental and brain health, but a major concern for people and society. In order to avoid the above-mentioned concerns, the best use of health communication strategies and HIT to improve health outcomes for people and access to quality of health care, society should recognize proper use of IT properties and also learn useful skills to use it well and properly. We live in the world of speed and in the current process, IT has the potential to help us. People should learn about these applicants' positive and negative aspects available today. A 2012 study by the University of Southern California also found that unprotected adolescent sexual activity was more common among smartphone owners and also through Internet communication or any backlit devices, overdose of misuse can also seriously affect sleep cycles [4].

People's addiction to IT applicants could cause a significant brain imbalance and how their brain works, severe anxiety and fatigue. There are also other symptoms typical of online addicts like: Feelings of guilt, anxiety, depression, dishonesty, euphoria when in front of the computer, unable to keep timetables, no sense of time, isolation, defensiveness, work avoidance, agitation, back pain, headaches, weight gain or loss, disturbances in sleep, carpal tunnel syndrome, blurred or strained vision, RF-EMFs via wireless, changes in brain activity, reaction times, and sleep patterns, tired and stinging eyes [5]. However, it should be considered and a great concern for human beings to be aware of the use of IT today and we should educate and train people and mostly young people to make the best use of IT and keep it away from our children when and where it should be, and we should also not neglect the necessary and varied IT applications that are useful for making a healthy and developed IT-based society. The observed asymmetry between positive and negative aspects of IT may be one of the reasons that concerns people and fears about the dangers that IT applicants face in modern society. Then, social health error and unsafe use of IT is a pressing issue, mostly by changing our care systems through the use of IT. Although IT is not the only way to solve this problem, because IT is highly complex and will require the attention of many, it can play a key and important role in putting it in the right way. The highest priority of the IT community is to assess the effects of IT on social health and to minimize the concerns.

\section{References}

1- Galt KA, Fuji KT, Kaufman TK, Shah SR. Health information technology use and patient safety: study of pharmacists in Nebraska. Pharmacy (Basel)2019; 7(1):7. 2- Tavakolizadeh J, Atarodi A, Ahmadpour S, Pourgheisar A. Health status and demographic factors among the students of Gonabad university of medical sciences in 2011-2012. Razavi International Journal of Medicine2014; 2(1): Published online

3- Nwachukwu Ch, Onyenankeya K. Use of smartphones among college students in nigeria: revelations and reflections. Journal of Communication2017; 8(2):171-82. 4- Cheever NA, Rosen LD, Carrier LM, Chavez A. Out of sight is not out of mind: The impact of restricting wireless mobile device use on anxiety levels among low, moderate and high users. Computers in Human Behavior 2014; 37 : 290-7.

5- Choi YH, Park SK. Environmental exposures to lead, mercury, and cadmium and hearing loss in adults and adolescents: KNHANES 2010-2012. Environ Health Perspect2017; 125 (6): 067003.

\footnotetext{
Copyright(C) 2016 ASP Ins. This open-access article is published under the terms of the Creative Commons Attribution-NonCommercial 4.0 International License which permits Share (copy and redistribute the material in any medium or format) and Adapt (remix, transform, and build upon the material) under the Attribution-NonCommercial terms.
} 